\title{
La falsificación de instrumentos privados: ¿una estafa especial?*
}

\author{
Laura Mayer Lux**
}

\section{RESUMEN}

El presente trabajo tiene por objeto controvertir la tesis en donde la falsificación de instrumentos privados es una forma especial de estafa. Con este fin se indican semejanzas y diferencias entre las nociones de falsedad y engaño. Posteriormente y considerando la regulación de los tipos de falsedad $y$ de estafa del Código Penal chileno, se apuntan varias distinciones entre ambos delitos. Dichas distinciones se centran en su origen y evolución histórica; en la idoneidad de la afirmación mendaz exigida; en la estructura de ambas figuras; en el bien jurídico protegido por cada una de ellas; en el carácter del perjuicio; $y$, finalmente, en la función que desempeña el perjuicio en uno y otro tipo penal.

Documento - falsedad - engaño

\section{Counterfeit of private documents: a special kind of fraud?}

\begin{abstract}
This paper aims to challenge the thesis according to which counterfeiting private documents is a special form of fraud. For this purpose, it highlights the similarities and differences between the concepts of falsehood and deception. Subsequently, considering the regulating of the Chilean Penal Code, a number of distinctions between these two crimes are observed. Such distinctions focus on the historical origin and evolution; the suitability of the mendacious statement required; the structure of both criminal offences; object protected by each of them; the nature of the damage; and, finally, the role of the damage in each offence.
\end{abstract}

$$
\text { Document - falsehood - deception }
$$

* Trabajo escrito en el marco del Proyecto Fondecyt de Iniciación 11121373 titulado "La delimitación del tipo penal de estafa en el ordenamiento jurídico chileno”, dirigido por la autora en la Pontificia Universidad Católica de Valparaíso.

** Abogada, Doctora en Derecho, Profesora de Derecho Penal, Pontificia Universidad Católica de Valparaíso, Chile. laura.mayer@ucv.cl.

Agradezco las valiosas observaciones del Profesor Jaime Vera Vega para la elaboración del presente trabajo.

Artículo recibido el 29 de marzo de 2014 y aceptado para su publicación por el Comité Editorial el 29 de octubre de 2014. 


\section{Planteamiento del problema}

L a jurisprudencia chilena dominante en la actualidad sostiene que la falsificación de instrumentos privados es una forma especial de estafa, cuya particularidad vendría dada por las singularidades de su engaño típico ${ }^{1}$. Así, de acuerdo con esta posición, mientras que la estafa puede ser cometida con cualquier clase de engaño idóneo $^{2}$, la falsificación de instrumentos privados supone engañar, no solo en un soporte especial -un documento privado-, sino que además de acuerdo con alguna de las modalidades indicadas en el artículo 193 del Código Penal chileno (en adelante, CP) ${ }^{3}$.

Politoff, Matus y Ramírez, en su obra dedicada a la Parte Especial, abordan la regulación de la falsificación de instrumentos privados de una manera que escapa a la regla general y que sigue el planteamiento jurisprudencial indicado. En efecto, dichos autores, en lugar de analizar la falsificación de documentos privados a continuación de las falsedades en instrumentos públicos ${ }^{4}$, lo hacen dentro del Capítulo dedicado a los "Delitos de enriquecimiento por defraudación: estafas y otros engaños" ${ }^{5}$. En dicho apartado se desarrolla el tema de la "estafa por medio de falsificación de instrumento privado o mercantil (arts. 197 y s. CP)”, efectuándose las siguientes afirmaciones:

"El engaño consiste en la falsificación y sus formas son las del art. 193 CP. Se trata de una estafa, pues aunque operan los mecanismos de la falsificación documental, la ley exige el perjuicio, y que ese perjuicio haya sido querido por el autor de la falsificación como resultado de la misma, que no es así otra cosa que un medio para engañar a otra. Las penas se agravan si los instrumentos falsificados son 'letras de cambio u otra clase de instrumentos mercantiles"'”.

\footnotetext{
${ }^{1}$ Cfr. SCS, de 31 de agosto de 2005, Rol: 796-03, fundamento jurídico noveno; SCA de Coyhaique, de 22 de marzo de 2006, Rol: 23-2006, fundamento jurídico sexto; SCA de Concepción, de 8 de enero de 2008, Rol: 2202-2005, fundamento jurídico segundo. Así también Etcheberry, A., Derecho Penal, Parte Especial, Tomo IV, reimpresión de la $3^{a}$ edición, Editorial Jurídica de Chile, Santiago, 2010, p. 174. Sobre el punto véase también Balmaceda, G., "El delito de estafa en la jurisprudencia chilena", en Revista de Derecho de la Universidad Austral de Chile, Volumen XXIV, julio 2011, p. 81.

${ }^{2}$ Idoneidad que, para esa misma jurisprudencia, se satisface con la realización de una puesta en escena o mise en scène. Véase, por todas, SCS, de 17 de junio de 1999 (recurso de casación en el fondo), en Revista de Derecho y Jurisprudencia y Gaceta de los Tribunales, No 2, 1999, pp. 159-164 y STJOP (2º de Santiago, de 25 de mayo de 2008, Causa RIT No 48-2008.

${ }^{3}$ Restrictivo Etcheberry, Derecho Penal, Parte Especial, Tomo IV, pp. 173 y s. Sobre dicha interpretación restrictiva véase Vargas, T., “'Daño del engaño’ en documentos privados. Aproximación al perjuicio en la falsificación de instrumentos privados”, en Revista de Derecho de la Universidad Austral de Chile, Volumen XXIV, diciembre 2011, pp. 184 y s.

${ }^{4}$ Por todos Garrido Montt, M., Derecho Penal, Parte Especial, Tomo IV, 4 a edición, Editorial Jurídica de Chile, Santiago, 2008, pp. 66 y ss. en relación con pp. 86 y ss.

${ }^{5}$ Politoff, S.; Matus, J.P.; Ramírez, M.C., Lecciones de Derecho Penal chileno, Parte Especial, $2^{\text {a }}$ edición, Editorial Jurídica de Chile, Santiago, 2005, p. 411.

${ }^{6}$ Politoff; Matus; Ramírez, Lecciones, p. 451.
} 
Por su parte, en el Capítulo 21 de sus Lecciones, Parte Especial, en el que se abordan las "Falsedades documentales", Politoff, Matus y Ramírez vuelven a escaparse de la regla general del tratamiento dogmático de esta materia, efectuando, en el apartado dedicado a la falsificación de instrumentos privados, una remisión del siguiente tenor:

"La falsificación de instrumentos privados del $§ 5$ del Tít. IV Libro II es, como hemos hecho notar anteriormente, un atentado contra el patrimonio y no una clase de falsedad que afecte la fe pública, por lo que su tratamiento se ha expuesto someramente junto con el de las estafas" 7 .

Que una estafa pueda cometerse mediante un instrumento privado falso es un asunto que no merece mayor discusión. Lo que sí resulta controvertible es la relación de especialidad que se plantea entre la estafa y la falsificación de documentos privados. En este orden de ideas, el presente trabajo tiene por objeto demostrar que la falsedad en instrumentos privados no es una estafa especial. Con este fin, se recurrirá al origen y evolución histórica de ambas figuras delictivas, así como a fundamentos relativos a la idoneidad del comportamiento, a la estructura del tipo, al bien jurídico tutelado -incluyendo razones de índole sistemática-, al carácter del perjuicio exigido y al papel que este desempeña en uno y otro tipo penal. De demostrarse lo anterior, en la práctica, se justificaría tanto un tratamiento separado de ambos delitos en las obras de la Parte Especial como -ante todo- un desarrollo jurisprudencial diverso del que hasta ahora han tenido los fallos de los Tribunales chilenos.

\section{FALSIFICACIÓN DE INSTRUMENTO PRIVADO Y ENGAÑO TÍPICO EN LA ESTAFA}

\section{Falsedad y engaño como actos de habla ilocucionarios}

Sabido es que Austin distingue tres dimensiones o aspectos de un acto de habla, a saber: el acto locucionario, el acto ilocucionario y el acto perlocucionario ${ }^{8}$, los que aluden, respectivamente, a decir algo (locución); hacer algo al decir algo (ilocución); y, provocar un efecto cuando se hace algo al decir algo (perlocución) ${ }^{9}$. Dicha forma de analizar la comunicación parte de una equiparación entre comunicación y comportamiento

7 Politoff; Matus; Ramírez, Lecciones, p. 570.

${ }^{8}$ Austin, J.L., How to do things with words, $2^{\text {a }}$ edición, Harvard University Press, Cambridge, 1975, pp. 98 y ss.

${ }^{9}$ Habermas, J., Theorie des kommunikativen Handelns, Tomo 1, Suhrkamp, Frankfurt am Main, 1995, p. 389. 
humano ${ }^{10}$, en el sentido de que "hacer uso del lenguaje supone ejecutar acciones"11, equiparación que Mañalich sintetiza en los siguientes términos:

"Hablar (ya) no solo es decir, hablar es hacer: hablar es hacer cosas diciendo. Y lo que se hace cuando se habla es lo que se expresa en la noción de acto ilocucionario"12.

La equiparación entre comunicación y acción puede plantearse respecto de toda conducta humana. Ahora bien, existen comportamientos delictivos que, en tanto presuponen la utilización del lenguaje -sea oral, escrito o gestual-, hacen de esa equiparación algo más evidente que en otras conductas típicas. Tal es el caso de diversos tipos penales diseminados a lo largo del CP que, de una u otra manera, demandan el empleo del lenguaje para la comisión de las conductas que incriminan ${ }^{13}$, al punto que es posible sostener que constituyen una categoría particular de delitos. En esa línea, más de algún autor ha intentado efectuar una suerte de paralelismo entre la obra de Austin, relativa a cómo hacer cosas con palabras, y el empleo de palabras como medio de comisión de delitos ${ }^{14}$ o, lo que es lo mismo, cómo cometer delitos con palabras ${ }^{15}$.

En los delitos que se cometen con palabras o, en la terminología utilizada por Austin, que se ejecutan por medio de "actos de habla", destacan la calumnia y las injurias ${ }^{16}$, las amenazas ${ }^{17}$, el falso testimonio ${ }^{18}$, las falsedades y la estafa ${ }^{19}$. El uso del lenguaje en todos estos delitos supone, por una parte, la emisión de un mensaje comunicativo y, por otra, la recepción de dicho mensaje comunicativo por parte de un sujeto distinto del emisor. El receptor del mensaje y el ofendido por el delito pueden o no $\operatorname{coincidir}^{20}$, lo

${ }^{10}$ Cfr. Wittgenstein, L., "Philosophische Untersuchungen", en Werkausgabe Band 1, Suhrkamp, Frankfurt am Main, p. 250 (23). Véase también Alcácer Guirao, R., "Cómo cometer delitos con el silencio. Notas para un análisis del lenguaje de la responsabilidad”, en de Toledo y Ubieto, E. O. et al. (coord.), Estudios penales en recuerdo del profesor Ruiz Antón, Tirant lo Blanch, Valencia, 2004, pp. 22 y s., p. 25.

11 Ruiz Antón, L.F., "La acción como elemento del delito y la teoría de los actos de habla: cometer delitos con palabras", en ADPCP, Tomo LI, 1998, p. 8. A la inversa, también puede plantearse que la acción, en tanto expresa algo, es comunicación (cfr. Alcácer Guirao, "Cómo cometer delitos con el silencio", p. 39).

${ }^{12}$ Mañalich, J.P., “¿La comisión de delitos mediante la imputación de delitos? Los delitos contra el honor bajo la teoría de los actos de habla”, en Revista Peruana de Doctrina y Jurisprudencia Penales, No 6, 2005, p. 212.

${ }^{13}$ Véase Ruiz Antón, "La acción como elemento del delito y la teoría de los actos de habla”, p. 5, p. 21.

${ }^{14}$ Cfr. Polaino Navarrete, M.; Polaino-Orts, M., Cometer delitos con palabras, Teoría de los actos de habla y funcionalismo jurídico-penal, Dykinson, Madrid, 2004, pp. 61 y s.

15 En este contexto el término "palabra" o "acto de habla" debe entenderse en sentido amplio y no meramente literal, como equivalente a acto comunicativo o, simplemente, a comunicación (oral, escrita o gestual).

16 Véase Mañalich, “¿La comisión de delitos mediante la imputación de delitos?”, pp. 206 y ss.

17 Véase Guzmán Dalbora, J.L., El delito de amenazas, Legal Publishing, Santiago, 1999, p. 175.

${ }^{18}$ Cfr. Ruiz Antón, "La acción como elemento del delito y la teoría de los actos de habla", pp. 5 y s., p. 21.

${ }^{19}$ Véase Mayer Lux, L., Die konkludente Täuschung beim Betrug, V\&Ruprecht unipress - Bonn University Press, Göttingen, 2013, pp. 15 y ss.

${ }^{20}$ Mañalich, “¿La comisión de delitos mediante la imputación de delitos?”, p. 208. 
ello dará lugar a una relación (comunicativa) triangular, cuyo paradigma en el caso de la estafa es la denominada estafa procesal.

Independientemente de la especie concreta de acto de habla que se lleve a cabo mediante los delitos de calumnia, injurias, amenazas, falso testimonio, falsedades o estafa -que, en todo caso, habitualmente supondrá la realización de una afirmación ${ }^{21}-$, todo delito que se cometa con palabras implicará, a lo menos, la ejecución de un acto de habla ilocucionario $-y$, consiguientemente, de un acto locucionario como presupuesto de aquel-. Que se verifique un acto de habla perlocucionario dependerá de si acaso quien calumnia o injuria también logra insultar a su interlocutor, de si quien amenaza es capaz de intimidar al destinatario del mensaje, o de si quien efectúa una afirmación falsa -sea que cometa falso testimonio, falsedad o estafa ${ }^{22}$ - logra engañar al receptor de la misma. Esta distinción no implica, necesariamente, una correspondencia entre el acto ilocucionario o perlocucionario y las etapas de desarrollo del delito (tentativa, frustración, consumación); o entre el acto ilocucionario o perlocucionario y los delitos de mera actividad o de resultado. Por ejemplo, aunque se sostenga que el falso testimonio es un delito de mera actividad ${ }^{23}$, quien recibe el mensaje comunicativo del testigo (perito o intérprete) puede resultar engañado en virtud de la afirmación falsa emitida (acto perlocucionario), efecto que no será necesario para que se den los elementos típicos de dicha figura (consumación), de acuerdo con la ley chilena.

\section{Falsedad y engaño; falsificar o falsear y engañar}

Desde un punto de vista etimológico, no existe diferencia entre las nociones de falsedad y engaño. Así, se sabe que la voz "falsedad" proviene del verbo latín fallere, que significa "engaño" 24 , esto es, afirmar algo contrario a la verdad, imitándola ${ }^{25}$. El

${ }^{21}$ Ello, atendido a que muchos de esos delitos parten de la existencia o inexistencia de un hecho, y sabido es que lo que podemos afirmar lo denominados "hecho" (cfr. Habermas, J., Wabrheit und Rechtfertigung, Suhrkamp, Frankfurt am Main, 2004, p. 321). La realización de una afirmación falsa es un presupuesto de los delitos de falsedad y estafa. En los delitos contra el honor, ello también parece necesario si se reconoce a su respecto la llamada exceptio veritatis y, al menos, en las injurias que suponen realizar una imputación falsa, así como en la calumnia, ya que una imputación (falsa) es "la aseveración [falsa] de que un sujeto ha cometido un delito” (Mañalich, “'La comisión de delitos mediante la imputación de delitos?”, p. 210). En las amenazas, la exigencia de seriedad también parece apuntar a la realización de un acto de habla asertivo.

${ }^{22}$ Cfr. Ruiz Antón, "La acción como elemento del delito y la teoría de los actos de habla”, p. 29.

23 Véase Rodríguez Collao, L.; Ossandón Widow, M.M., Delitos contra la función pública, $2^{\text {a }}$ edición, Editorial Jurídica de Chile, Santiago, 2008, p. 256.

${ }^{24}$ Mommsen, T., El Derecho Penal Romano, Tomo 2, traducción de Dorado, P., La España Moderna, Madrid, 1898, p. 139. Véase también García Cantizano, M., Falsedades documentales (En el Código Penal de 1995), Tirant lo Blanch, Valencia, 1997, pp. 102 y s.

25 Villacampa Estiarte, C., La Falsedad Documental: análisis jurídico-penal, Cedecs, Barcelona, 1999, p. 320. Cfr. asimismo Silva Sánchez, J.M., "Las falsedades documentales”, en él mismo (dir.), Lecciones de Derecho Penal, Parte Especial, Atelier, Barcelona, 2006, p. 288; Vargas, “'Daño del engaño’ en documentos privados", p. 186 con nota 22. 
término "falso" o "falsedad" puede referirse a determinadas cosas, vgr. monedas o timbres $^{26}$ que, con la conducta consistente en alterarlas, falsificarlas o falsearlas, pierden su condición de auténticas o fieles respecto de otra cosa calificada de original. También puede emplearse el término "falso" o "falsedad" para referirse a un objeto forjado o creado ex novo, sin imitar otro auténtico, pero atribuyéndole características que no corresponden con la realidad.

Pese a que la acción consistente en alterar o falsificar un documento también implica una afirmación falsa -por ejemplo, que tal documento se extendió el 31 de diciembre de 2013, no obstante su emisión data del 2 de enero 2014-, en el engaño la existencia de una aserción mendaz acerca de determinadas cosas puede constatarse más directamente. De cierta manera, en las falsedades, la alteración de cuestiones establecidas conlleva o encierra una afirmación falsa relativo a hechos, cuyo destinatario, generalmente, carece de concreción ${ }^{27}$, así como de relevancia para establecer si concurren o no los elementos típicos ${ }^{28}$. En cambio, en la estafa, la realización de una afirmación falsa -esto es, la acción de engañar a otro-, se refiere a hechos a precisos que, comunicativamente, son presentados al disponente del patrimonio de manera distinta a como existen en la realidad. Con ello se busca que sea ese sujeto quien realice un acto de disposición patrimonial perjudicial determinado por error, resultado indispensable para que el tipo de estafa alcance el grado de consumado.

Desde un punto de vista penal, si bien los conceptos de falsedad y engaño suponen la realización de una afirmación (falsa) o, lo que es lo mismo, de un acto de habla asertivo (mendaz), la forma de plasmar dicha afirmación en la falsificación de instrumentos privados se restringe a un documento que revista ese carácter ${ }^{29}$. En cambio, el engaño en la estafa no requiere su plasmación en dicho soporte, pudiendo llevarse a cabo, perfectamente, un engaño típico en forma verbal ${ }^{30}$ o aun mediante gestos ${ }^{31}$. Además, el comportamiento típico en el delito de estafa es siempre un engaño patrimonial, esto es, un engaño que se emplea como medio para la afectación de los intereses patrimoniales de otro. Se trata de una conducta que no se agota en una mera "afirmación falsa con perjuicio" (plasmada en un documento privado), constituyendo, en cambio, un mecanismo de instrumentalización del disponente del patrimonio ${ }^{32}$ y de provocación de un perjuicio patrimonial ajeno.

${ }^{26}$ Así la tercera acepción de "falsedad” contenida en el Diccionario de la Real Academia Española (RAE).

${ }^{27}$ Cfr. Jakobs, G., Falsedad documental, Revisión de un delito de engaño, traducción de López Barja de Quiroga, J.; Rey Sanfiz, L.C., Marcial Pons, Madrid, 2011, p. 42, aludiendo a supuestos en que "los documentos están destinados potencialmente a cualquier persona”. Véase también Creus, C., Falsificación de documentos en general, $3^{\text {a }}$ edición, Astrea, Buenos Aires, 1999, pp. 1 y ss.

${ }^{28}$ De forma análoga Villacampa Estiarte, La Falsedad Documental, pp. 612 y ss.

${ }^{29}$ Cfr. Villacampa Estiarte, La Falsedad Documental, p. 610.

${ }^{30}$ Por todos Mitsch, W., Strafrecht Besonderer Teil 2, Vermögensdelikte (Kernbereich), Parte 1, 2a edición, Springer, Berlin, 2003, p. 425.

${ }^{31}$ Véase solamente Schmidhäuser, E., Strafrecht Besonderer Teil, 2a edición, Mohr, Tübingen, 1983, p. 116.

32 Un planteamiento similar puede verse en Vargas, T., “"Engaño patrimonial' y perjuicio. Análisis desde la práctica nacional”, en Doctrina y Jurisprudencia Penal, N² 2, 2010, p. 57. 


\section{Falsedad documental, engaño y mentira}

Históricamente se ha distinguido entre el engaño típicamente relevante para efectos de la estafa y una simple mentira sin relevancia penal, que no sería suficiente para cometer dicho delito ${ }^{33}$. Un sector de la doctrina, todavía minoritario, discute la corrección del planteamiento anterior ${ }^{34}$, principalmente en atención a la regulación de la estafa contenida en el $\mathrm{CP}^{35}$, pero también invocando razones de orden político-criminal ${ }^{36}$.

El término "mentira" tiene un componente de índole moral ${ }^{37}$, que lo diferencia de los conceptos de engaño y de falsedad en tanto conductas penalmente típicas. Con todo, la voz "mentira" tiene elementos que también son propios del engaño y de la falsedad ${ }^{38}$.

Por una parte, es posible entender la noción de falsedad en el sentido de una aserción falsa, y sabemos que una mentira también es una afirmación mendaz. Sin embargo, es característico de las falsedades documentales -y no de las (simples) mentiras-, precisamente, su plasmación en un soporte material ${ }^{39}$ que, en la falsificación de instrumento privado, no pueda ser calificado de documento público u oficial ${ }^{40}$.

Por otra parte, el engaño en la estafa, en su vertiente activa, también supone la realización de una afirmación falsa, sea de manera expresa o concluyente, pero no se agota en ella. El engaño típico en el delito de estafa es siempre una afirmación falsa emitida como medio para la provocación de una disposición patrimonial perjudicial determinada por el error de quien dispone del patrimonio.

La relación entre los conceptos de mentira y de falsificación de documentos o de engaño típico a título de estafa no es exactamente una relación de género (mentira) y especie (falsedad y engaño), pues si se atribuye al concepto de mentira una connotación

33 Así Carrara, F., Programa de Derecho Criminal, Parte Especial, Volumen IV, traducción de Ortega, J. y Guerrero, J., Temis, Bogotá, 1959, p. 426; Etcheberry, A., Derecho Penal, Parte Especial, Tomo III, reimpresión de la $3^{\text {a }}$ edición, Editorial Jurídica de Chile, Santiago, 2010, pp. 393 y s.; Soler, S., Derecho Penal Argentino, Tomo IV, $3^{\text {a }}$ reimpresión total, Tipográfica Editora Argentina, Buenos Aires, 1956, p. 334.

${ }^{34}$ Véase Mera, J., Fraude civil y penal. El delito de entrega fraudulenta, reimpresión de la $3^{\text {a }}$ edición, Legal Publishing, Santiago, 2005, p. 34.

35 Cfr. Politoff; Matus; Ramírez, Lecciones, p. 444.

36 Cfr. Hernández, H., "Aproximación a la problemática de la estafa”, en Cury, E. et al., Problemas Actuales de Derecho Penal, Universidad Católica de Temuco, Temuco, 2003, p. 162.

${ }^{37}$ Calle Rodríguez, M. V., Falsedades documentales no punibles, Editoriales de Derecho Reunidas, Madrid, 1998, pp. 22 y s.

38 Alejandre, J.A., "Estudio histórico del delito de falsedad documental", en Anuario de Historia del Derecho Español, Tomo XLII, 1972, p. 120.

39 Para el análisis que aquí se efectúa carece de relevancia la discusión relativa al carácter escrito del soporte material que conforma al documento. Para dicha discusión cfr., por ejemplo, Cousiño, L., "La falsificación de instrumento privado (1) (Ensayo de Construcción Jurídica del Delito en Chile)", en Revista de Ciencias Penales, Tomo VII, 1944, pp. 19 y s.; Villacampa Estiarte, La Falsedad Documental, pp. 103 y ss.

${ }^{40}$ Casas Barquero, E., El delito de falsedad en documento privado, Bosch, Barcelona, 1984, p. 224. De esta forma, el instrumento privado tiene, respecto del público, un carácter residual. Cfr. solamente Bustos Ramírez, J., Obras Completas, Derecho Penal, Parte Especial, Tomo III, $2^{\text {a }}$ edición, Ediciones Jurídicas de Santiago, Santiago, 2009, p. 625, comentando el artículo 395 del CP español. 
moral, que identifique dicho comportamiento con algo "malo" o que "no debe hacerse", advertiremos que el término mentira también puede tener un sentido específico, que se aleja de lo jurídico-penalmente relevante.

Tampoco es posible sostener que la única diferencia entre la estafa y la falsificación de instrumento privado estribe en que el medio engañoso esté más particularizado en el artículo $197 \mathrm{CP}^{41}$, cuestión que supone partir de la idea -que, como veremos, aquí no se comparte ${ }^{42}$-, de que el bien jurídico protegido por la estafa y por la falsificación de documentos privados es el mismo, a saber, los intereses patrimoniales ajenos ${ }^{43}$.

\section{DifERENCIAS ENTRE LA FALSIFICACIÓN DE INSTRUMENTOS} PRIVADOS Y LA ESTAFA

\section{Diferencias entre la falsificación de instrumentos privados y la estafa desde el punto de vista de su origen y evolución histórica}

Históricamente las falsedades, como delitos estrictamente penales, son anteriores a la estafa, al menos a la estafa como la entendemos hoy, esto es, como un delito que supone engaño, error, disposición patrimonial, perjuicio patrimonial y relación de causalidad entre los elementos indicados ${ }^{44}$. En este orden de ideas, las falsedades fueron reconocidas ya en el Derecho Romano por medio del crimen falsi, crimen que tuvo un carácter público equivalente al de un delito penal, atendida la afectación de la publica fides que él suponía ${ }^{45}$.

Partiendo por la falsificación de testamentos y de monedas ${ }^{46}$, las falsedades fueron extendiéndose a varias hipótesis de la más diversa índole, muchas vinculadas con determinados objetos (vgr. documentos públicos y privados ${ }^{47}$ ); otras, con el ejercicio de ciertas actuaciones judiciales $^{48}$ (por ejemplo, el falso testimonio o el falso patrocinio

${ }^{41}$ Etcheberry, Derecho Penal, Parte Especial, Tomo IV, p. 177.

42 Sobre este asunto se volverá en el punto III.4.

43 Cfr. Garrido Montt, Derecho Penal, Parte Especial, p. 87 en relación con pp. 330 y s.

${ }^{44}$ En realidad, como plantea Lackner, K., “\$ 263”, en Jescheck, H. et al. (edit.), Leipziger Kommentar, Strafgesetzbuch, Großkommentar, Tomo 6, $10^{a}$ edición, Walter de Gruyter, Berlin, 1988, número marginal 1, la estafa, con su actual fisionomía, es resultado del desarrollo jurídico acaecido recién durante el siglo XIX.

45 Schaffstein, F., "Das Delikt des Stellionatus in der gemeinrechtlichen Strafrechtsdoktrin. Eine Studie zur Entstehungsgeschichte des Betrugstatbestandes”, en Behrends, O. et al. (edit.), Festschrift für Franz Wieacker zum 70. Geburtstag, Vandenhoeck \& Ruprecht, Göttingen, 1978, p. 281.

46 Véase Mommsen, El Derecho Penal Romano, pp. 142 y ss.; Rojas, L.E., "Historia dogmática de la falsedad documental", en Revista de Derecho de la Pontificia Universidad Católica de Valparaíso, Volumen XXXIX, Semestre II, 2012, p. 548.

47 Cfr. Schilling, G., Der strafrechtliche Schutz des Augenscheinsbeweises. Ein Beitrag zur Lebre von der Beweismittelfälschung, Ludwig Röhrscheid, Bonn, 1965, p. 37.

${ }^{48}$ Cfr. D'ors, A., "Contribuciones a la historia del 'crimen falsi”, en Studi in onore di Edoardo Volterra, Tomo II, Giuffrè, Milán, 1969, pp. 553 y ss. 
forense ${ }^{49}$ ), por solo citar algunos ejemplos. Lo anterior permite plantear una continuidad en el desarrollo histórico de las falsedades, las que con más o menos matices también son reconocidas en los Códigos Penales de nuestros días.

Lo interesante de la regulación romana de las falsedades es que el paradigmático supuesto del crimen falsi recaído en testamentos se refería a un instrumento privado desde el punto de vista de su emisión (el testamento), pero que gozaba de una relevancia jurídica y social equivalente a la de los documentos públicos ${ }^{50}$. En otras palabras, se contemplaba un supuesto de falsificación de instrumento privado como delito contra intereses públicos y no como un tipo delictivo que atentaba contra intereses jurídicoprivados, vgr. los intereses patrimoniales ajenos. Además, en ese entonces se exigía que el falsum importara un daño ${ }^{51}$, el que, más que identificarse con el resultado del comportamiento $^{52}$, parecía vincularse con la gravedad socialmente atribuida a las acciones falsarias sancionadas.

Distinta es la evolución experimentada por el delito de estafa. Este, tuvo como antecedente histórico, entre otros, al crimen falsi ${ }^{53}$. Así, por ejemplo, se castigaba a título de falsum la falsificación de pesos o medidas ${ }^{54}$, conducta que se asemeja notoriamente al tipo del artículo 469 número $2^{\circ} \mathrm{CP}$, que castiga "[a] los traficantes que defraudaren usando de pesos o medidas falsos en el despacho de los objetos de su tráfico”. Fuera del crimen falsi, la estafa también tuvo como precursor histórico a otras instituciones romanas, vgr. el furtum ${ }^{55}$ y, principalmente, el stellionatus ${ }^{56}$. Dichas instituciones, a diferencia del falsum, constituyeron inicialmente delitos civiles ${ }^{57}$, teniendo el segundo, además de un carácter subsidiario ${ }^{58}$, "contornos muy vagos" 59 .

${ }^{49}$ Véase Ferruccio, G., Diritto Penale Romano, Volumen II, R. Zannoni, Padova, 1932, pp. 170 y s.

${ }^{50}$ Alejandre, "Estudio histórico del delito de falsedad documental", pp. 128 y s.

${ }^{51}$ Quintano Ripollés, A., La falsedad documental, Instituto Editorial Reus, Madrid, 1952, p. 34. Acerda de ello véase también Alejandre, "Estudio histórico del delito de falsedad documental", pp. 121 y s. con nota 10.

52 Cfr. Rojas, "Historia dogmática de la falsedad documental”, pp. 554 y s.

53 Cucumus, C., Ueber das Verbrechen des Betrugs, als Beytrag für Criminalgesetzgebung. Ein Programm, Nitribitt, Würzburg, 1820, pp. 103 y ss. También Tiedemann, K., "Vor § 263”, en Laufhütte, H. W. et al. (edit.), Leipziger Kommentar, Strafgesetzbuch, Großkommentar, Tomo 9, Parte 1, $12^{\text {a }}$ edición, Walter de Gruyter, Berlin, 2012, número marginal 13.

${ }^{54}$ Véase Ferruccio, Diritto Penale Romano, p. 173.

55 Donna, E.A., Derecho Penal, Parte Especial, Tomo II-B, Rubinzal-Culzoni, Buenos Aires, 2001, p. 256. En la doctrina chilena véase Vargas, “'Daño del engaño’ en documentos privados”, pp. 186 y s. con nota 23.

${ }^{56}$ Carrara, Programa de Derecho Criminal, Volumen IV, p. 412. También Aguilar Aranela, C., Delitos Patrimoniales, Editorial Metropolitana, Santiago, 2008, p. 129 y Yubero, J., El engaño en el delito de estafa, $2^{\mathrm{a}}$ edición, Editorial Cruz del Sur, Santiago, 2010, pp. 21 y ss.

57 Véase Guzmán Brito, A., Derecho Privado Romano, Tomo II, Editorial Jurídica de Chile, Santiago, 1997, pp. 242 y ss., respecto del furtum, y Merkel, A., "Die Lehre vom strafbaren Betruge", en él mismo, Kriminalistische Abhandlungen, Tomo II, reimpresión de la edición de Leipzig de 1867, Detlev Auverman, Glashütten im Taunus, 1971, p. 16, en relación con el stellionatus.

${ }^{58}$ D'ors, "Contribuciones a la historia del 'crimen falsi"”, p. 557; Mommsen, El Derecho Penal Romano, pp. 149 y ss.

59 Giuffrè, V., La repressione criminale nell'esperienza romana, 5a edición, Jovene, Nápoles, 1998, p. 111 (traducción de la autora). Similar Ferruccio, Diritto Penale Romano, p. 235. 
Durante la Edad Media la estafa siguió sin ser un delito autónomo; las conductas que hoy podrían catalogarse como tales fueron sancionadas fundamentalmente a título de falsum. Este, a diferencia del falsum romano, que se centraba en falsedades de relevancia pública, constituyó una figura genérica, que incluía casos de fraude patrimonial ${ }^{60}$, pero también otros, que hoy serían catalogados derechamente como supuestos de falsedad ${ }^{61}$. En esta etapa no existe una separación nítida entre la estafa y las falsedades, ya que ambas eran entendidas como hipótesis de suplantación dolosa de la verdad ${ }^{62}$.

El divorcio entre la estafa y las falsedades solo se producirá cuando la primera deje de centrarse en el falsum y pase a considerar, en forma creciente, el daño patrimonial que se provoca con el mismo ${ }^{63}$. Solo entonces se irán perfilando los contornos de la estafa como delito patrimonial. Las falsedades, por su parte, seguirán centradas en el falsum, comportamiento que, a diferencia del engaño típico en la estafa, se vinculará con la fe pública o con otros intereses de naturaleza (supraindividual) análoga.

\section{Diferencias entre la falsificación de instrumentos privados y la estafa desde el punto de vista de la idoneidad de la afirmación mendaz}

En cuanto a la idoneidad de la afirmación falsa que supone toda estafa y toda falsedad, cabe hacer presente algunas diferencias que se desprenden de ciertas normas del CP y que, nos obligan a adentrarnos, aunque sea brevemente, en la antigua discusión relativa a si el engaño típico a título de estafa exige o no una mise en scène $e^{64}$. Se vincula con dicha exigencia la doctrina que demanda que el engaño típico sea un "engaño bastante" 65 o "suficiente" 66 como para inducir a otro a error ${ }^{67}$.

El engaño activo en la estafa es una afirmación falsa sobre hechos típicamente relevantes, mientras que el engaño omisivo es la ausencia de una afirmación verdadera debida sobre la base de la existencia de una posición de garante. El engaño activo en la estafa no exige una mise en scène, pudiendo perfectamente configurarse un supuesto de estafa en caso que se realice una afirmación mendaz sobre hechos típicamente relevantes,

${ }^{60}$ Cfr. Donna, Derecho Penal, Parte Especial, pp. 256 y s.

${ }^{61}$ En ese orden de ideas Kindhäuser, U., “\$ 263”, en Kindhäuser, U. et al. (edit.), Nomos Kommentar, Strafgesetzbuch, Tomo III, 4a edición, Nomos, Baden-Baden, 2013, número marginal 4.

${ }^{62}$ Schaffstein, "Das Delikt des Stellionatus in der gemeinrechtlichen Strafrechtsdoktrin”, p. 284.

${ }^{63}$ Cfr. Tiedemann, "Vor $\$ 263$ ", número marginal 14.

${ }^{64}$ Fundamental Carrara, Programa de Derecho Criminal, Volumen IV, p. 426. Con matices Soler, Derecho Penal Argentino, pp. 333 y ss. Sobre el punto véase asimismo Balmaceda, "El delito de estafa en la jurisprudencia chilena”, p. 63 con nota 14, con numerosas referencias jurisprudenciales.

${ }^{65}$ Por todos González Rus, J.J., "Delitos contra el patrimonio y contra el orden socioeconómico (V). Las defraudaciones. La estafa”, en Morillas Cueva, L. (coord.), Sistema de Derecho Penal Español, Parte Especial, Dykinson, Madrid, 2011, p. 486.

${ }^{66}$ Labatut, G., Derecho Penal, Tomo II, reimpresión de la $7^{\text {a }}$ edición actualizada por el profesor J. Zenteno,

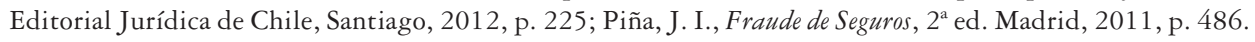

${ }^{67}$ Jiménez de Asúa, L., Crónica del Crimen, $7^{\text {a }}$ edición, LexisNexis, Buenos Aires, 2005, p. 322. 
que no vaya acompañada o reforzada por apariencia objetiva externa alguna ${ }^{68}$. Incluso es posible que se cometa un engaño burdo, siempre que este se refiera a hechos típicamente relevantes y sin perjuicio de que su ejecución provoque que la estafa solo pueda sancionarse a título de delito frustrado, en caso que el disponente del patrimonio, por ejemplo, haya advertido que la afirmación efectuada era mendaz y, consiguientemente, haya decidido no realizar la disposición patrimonial (perjudicial) ${ }^{69}$. En Chile, la exigencia de "idoneidad" del engaño, de gran acogida en el contexto iberoamericano ${ }^{70}$, tiene sentido respecto de la estafa consumada, no así de la tentada o frustrada, que perfectamente pueden ejecutarse mediante un engaño inidóneo para inducir a error. Dichas consideraciones se basan en diversas disposiciones, a saber, los artículos 171, 179 y $184 \mathrm{CP}$, ubicados en el mismo Título que la falsificación de instrumento privado ${ }^{71}$.

El artículo $171 \mathrm{CP}$ establece que "[s]i la falsificación o cercenamiento [de moneda] fueren tan ostensibles que cualquiera pueda notarlos y conocerlos a la simple vista, los que fabricaren, cercenaren, expendieren, introdujeren o circularen la moneda así falsificada o cercenada podrán ser castigados como responsables de estafas y otros engaños, con las penas que se establecen en el título respectivo".

Por su parte, el artículo 179 CP dispone que "[s]i la falsificación fuere tan grosera y ostensible que cualquiera pueda notarla y conocerla a la simple vista, los que falsificaren, expendieren, introdujeren o circularen los títulos así falsificados, podrán ser castigados como responsables de estafas y otros engaños con las penas que se establecen en el Título respectivo".

En fin, el artículo 184 CP establece que "[c]uando la falsificación fuere tan mal ejecutada que cualquiera pueda notarla y conocerla a la simple vista, los que la hubieren efectuado y los que expendieren o introdujeren el papel sellado o las estampillas así falsificados, podrán ser castigados como responsables de estafas y otros engaños con las penas que se establecen en el Título respectivo".

A las disposiciones transcritas subyace la idea de que las falsedades -no solo las de los artículos 171, 179 y $184 \mathrm{CP}$, pues no hay razones de peso para limitarse a ellas- no pueden ser tan ostensibles que cualquiera pueda notarlas y conocerlas a simple vista. Tampoco es posible que sean tan groseras o tan mal ejecutadas que cualquiera pueda notarlas y conocerlas fácilmente. Por el contrario, el legislador parte de la base de que el comportamiento falsario debe llevarse a cabo de tal manera, que el documento falso pueda utilizarse, esto es, entrar al tráfico jurídico y desempeñar -al menos formalmente- la función que le es propia. Para ello es necesario que su apariencia o contenido

${ }^{68}$ Así lo exige, en cambio, Etcheberry, Derecho Penal, Parte Especial, Tomo III, p. 393.

${ }^{69}$ En el mismo sentido Piña, Fraude de Seguros, pp. 148 y ss.

${ }^{70}$ Fontán Balestra, C., Derecho Penal, Parte Especial, 16 a edición actualizada por G. Ledesma, Abeledo-Perrot, Buenos Aires, 2002, pp. 486 y s.; García Cavero, P., Nuevas formas de aparición de la criminalidad patrimonial, Jurista Editores, Lima, 2010, p. 63; Magaldi Paternostro, M.J., “Arts. 248 a 254”, en Córdoba Roda, J. y García Arán, M. (dirs.), Comentarios al Código Penal, Parte Especial, Tomo I, Marcial Pons, Madrid, 2004, p. 746.

${ }^{71}$ Concerniente al punto ya había advertido Hernández, "Aproximación a la problemática de la estafa", pp. 161 y s.; también Politoff; Matus; Ramírez, Lecciones, p. 431. 
comunicativo parezca auténtico o veraz, o que el menos no resulte a todas luces contrario a tales atributos.

Que se establezca un requisito de idoneidad respecto de algunos de los supuestos de falsedad -los de los artículos 171, 179 y 184 CP- no implica que en las restantes figuras falsarias dicha exigencia no deba concurrir. En ciertas ocasiones -sea por razones de técnica legislativa o de otra índole- el legislador refuerza determinados requisitos en la descripción típica. Pero de ello no se sigue que solo en tales casos deba concurrir la exigencia que, únicamente en ese tipo específico, se enfatizó. Por ejemplo, en el delito de secuestro del artículo 141 CP se hace una alusión expresa al bien jurídico afectado, a saber, la "libertad" de la víctima. Tal referencia es excepcional dentro del CP, y no por ello va a plantearse que los restantes tipos de la Parte Especial, que no aluden explícitamente al bien jurídico, carecen de bien jurídico o no requieren una lesión o puesta en peligro del mismo ${ }^{72}$.

\section{Diferencias entre la falsificación de instrumentos privados y la estafa desde el punto de vista de la estructura típica}

El delito de estafa exige una serie de elementos que se encuentran vinculados (causalmente) entre $s^{73}$, a saber, engaño, error, disposición patrimonial, perjuicio patrimonial ${ }^{74}$. Esto implica que el sujeto activo del delito realiza un engaño (activo u omisivo), que provoca un error en el receptor del mismo, determinando que dicho receptor lleve a cabo, a su turno, una disposición patrimonial perjudicial a sus intereses o a los de un tercero.

La estafa es un delito de comunicación ${ }^{75}$. En ella, el disponente del patrimonio, que puede o no coincidir con la víctima perjudicada ${ }^{76}$, pero sí debe ser quien incurra en

72 Además, si se entendiera que solo los artículos 171, 179 y 184 CP exigen idoneidad de la acción falsaria, constituyendo, de esta forma, una excepción que confirma la regla de la punibilidad de las falsedades inidóneas, se produciría lo siguiente: solo las conductas de los artículos 171, 179 y 184 CP tendrían que ser idóneas para ser sancionadas penalmente. El comportamiento del artículo 197 CP podría ser castigado tanto si la falsedad es idónea como si es inidónea, pero siempre que exista un perjuicio para tercero. Y las restantes falsedades del CP podrían ser sancionadas sean idóneas o no (e importen o no un perjuicio para tercero). Ello, en primer lugar, podría acarrear penas desproporcionadas (por ejemplo, que se imponga la misma sanción a una falsedad idónea que a una falsedad inidónea); y, en segundo lugar, vulneraría el principio de intervención mínima, pues se estaría castigando penalmente comportamientos de escasa dañosidad social, que perfectamente podrían ser reprimidos por medio de mecanismos menos gravosos, vgr. civiles o administrativos.

${ }^{73}$ Cfr., por ejemplo, Bullemore, V.R.; Mackinnon, J.R., Curso de Derecho Penal, Parte Especial, Tomo III, LexisNexis, Santiago, 2005, p. 128; Hefendehl, R., "§ 263”, en Joecks, W. y Miebach, K. (edits.), Münchener Kommentar, Strafgesetzbuch, Tomo 4, Beck, München, 2006, número marginal 13.

${ }^{74}$ Véase solamente Antón Oneca, J., "Estafas”, en Mascareñas, C.E. (dir.), Nueva Enciclopedia Jurídica, Tomo IX, Editorial Francisco Seix, Barcelona, 1958, p. 57.

75 Por todos Tiedemann, K., "\$ 263”, en Laufhütte, H. W. et al. (edit.), Leipziger Kommentar, Strafgesetzbuch, Großkommentar, Tomo 9, Parte 1, $12^{\mathrm{a}}$ edición, Walter de Gruyter, Berlin, 2012, número marginal 4.

${ }^{76}$ Cfr., por ejemplo, Fischer, T., Strafgesetzbuch und Nebengesetze, $58^{a}$ edición, Beck, München, 2011, $\S 263$, número marginal 79 . 
error $^{77}$, basa su decisión de disponer o no del patrimonio (propio o ajeno) en la información proporcionada por el agente -o bien, en la omisión de una información debida, en caso que se acepte la posibilidad de cometer una estafa por omisión-.

La falsedad, en tanto supone la realización de una afirmación falsa, es al igual que el engaño en la estafa, un acto comunicativo que se dirige a otra persona, siendo (potencialmente) recibido e interpretado por alguien diverso de su autor ${ }^{78}$. No obstante, el carácter comunicativo de la estafa va más allá de la emisión y determinación del sentido de un mensaje. En la estafa, además de la realización de una afirmación mendaz sobre hechos típicamente relevantes, se verifica la disposición patrimonial (perjudicial determinada por error) de quien recibe e interpreta la información falsamente aseverada. Es decir, la disposición patrimonial (perjudicial y determinada por error) se basa en determinadas informaciones típicamente relevantes y se lleva a cabo porque se parte de la efectividad de las mismas. Como sostiene Vargas, "[e]l solo engaño no determina una estafa, sino que lo hace en cuanto medio para afectar el patrimonio ajeno"79.

Por otra parte, la estafa es un delito de autolesión ${ }^{80}$. El sujeto activo en la estafa no ataca directamente el patrimonio de otro, sino que requiere la conducta del disponente para concretar el perjuicio patrimonial que persigue. Es el propio disponente patrimonial quien provoca el perjuicio con su comportamiento, pero es el sujeto activo quien termina respondiendo de ese resultado, precisamente, por haber llevado a cabo el engaño típico que causó el error ${ }^{81}$. Que la estafa sea un delito de comunicación se vincula directamente con su carácter de autolesión, pues el daño patrimonial que (auto) provoca el disponente se basa en la información proporcionada (acción) o, en su caso, no proporcionada (omisión) por el agente, en contravención a una prohibición o a un mandato normativos.

En particular, la caracterización de la estafa como delito de autolesión ha sido utilizada para la delimitación entre el tipo penal de estafa y el delito de hurto. Este, conceptualmente, no implica una "autolesión", sino que una "heterolesión" de intereses patrimoniales ajenos, llevada a cabo por el sujeto activo de la conducta apropiatoria, sujeto que no requiere una actuación de la víctima para concretar dicho comportamiento. Pues bien, si tuviéramos que ubicar a la falsificación de instrumentos privados dentro de alguna de esas categorías, tendríamos que calificarla como un delito de "heterolesión",

77 Por todos Romero, G., Delito de estafa, 2a edición, Hammurabi, Buenos Aires, 1998, p. 234.

${ }^{78}$ En sentido análogo Puppe, I., Die Fälschung technischer Aufzeichnungen, Duncker \& Humblot, Berlin, 1972, p. 17. Véase también Guzmán Dalbora, El delito de amenazas, p. 169, empleando la voz "declaración” en el sentido de "movimiento de expresión [que] está destinado a ser percibido por otra persona", a fin de restringir las manifestaciones relevantes para el Derecho.

79 Vargas, “'Engaño patrimonial’ y perjuicio. Análisis desde la práctica nacional”, p. 59.

${ }^{80}$ Cfr., por ejemplo, Frisch, W., "Funktion und Inhalt des 'Irrtums' im Betrugstatbestand”, en Kaufmann, A. et al. (edit.), Festschrift für Paul Bockelmann zum 70. Geburtstag, Beck, München, 1979, pp. 657 y ss.; Hefendehl, “§ 263", número marginal 8.

${ }^{81}$ De forma análoga Piña, J.I., "Comentario a la SCA de Copiapó de 5 de octubre de 2000 sobre la imposibilidad de consumar la estafa con la disposición patrimonial de quien no ha sufrido el engaño (ROL 75087-2000)", en Doctrina y Jurisprudencia Penal, No 2, 2010, p. 99. 
al igual que el hurto. Quien lleva a cabo la falsedad en documento privado no requiere la realización de conducta alguna de otro -y menos de un disponente patrimonial- para lesionar el bien jurídico protegido. Basta con la falsificación, por una parte, y con el perjuicio de tercero, por la otra, sin que se necesite un acto de disposición patrimonial determinado por error, que una (causalmente) al engaño con el resultado típico (perjuicio patrimonial).

\section{Diferencias entre la falsificación de instrumentos privados y la estafa desde el punto de vista del bien jurídico tutelado. El problema del carácter del "perjuicio" exigido 82}

Si bien una primera aproximación puede identificar el bien jurídico subyacente a las figuras falsarias con la noción de fe pública ${ }^{83}$, en atención a la denominación del Título IV, Libro II CP, la idea de "fe", además de ser excesivamente amplia, tiene una connotación religiosa que resulta inapropiada para definir el objeto jurídico de un delito $^{84}$. En los hechos, la fe pública ha ido perdiendo terreno como interés afectado por los delitos de falsedad, dando paso a otros planteamientos más acordes con el estado actual de las relaciones jurídicas.

Hoy, la doctrina dominante considera que el bien jurídico protegido en los delitos falsarios es, genéricamente, la seguridad del tráfico jurídico ${ }^{85}$. Dicha noción, si bien supera

${ }^{82}$ Desde un punto de vista histórico, las falsedades fueron vinculadas con las nociones de "verdad" o de "derecho a la verdad" como objetos de tutela penal (cfr. Donna, E. A., "El bien jurídico en los delitos contra la fe pública”, en Urquizo Olaechea, J. [dir.], Modernas tendencias de dogmática penal y política criminal, Libro bomenaje al Dr. Juan Bustos Ramírez, Idemsa, Lima, 2007, pp. 268 y s.; Schilling, Der strafrechtliche Schutz des Augenscheinsbeweises, pp. 42 y ss. con referencias ulteriores). El correlato de este "derecho a la verdad" es un "deber de veracidad", el que, respecto de las falsedades, tradicionalmente no se ha demandado a los particulares (cfr. Vargas, T., "Comentario a la SCA de Antofagasta de 27 de junio de 2008 [ROL: 117-2008]", en Doctrina y Jurisprudencia Penal, No 3, 2010, pp. 84 y s.), salvo a propósito de la comisión de otros delitos y siempre que se den los requisitos típicos de esas otras figuras. Así, por ejemplo, a la estafa subyace una prohibición de efectuar afirmaciones falsas sobre hechos típicamente relevantes, esto es, aquellos que, según la relación negocial concreta que se verifique entre el agente y el disponente del patrimonio, sean manifiestamente determinantes para efectuar una disposición patrimonial racional. De ahí que sostener que en la estafa -como en la falsificación de instrumentos privados- los particulares tengan "deberes de veracidad" es inexacto. Primero, porque la noción de "veracidad” está cargada de una connotación moral, a causa de su ligazón con la idea de "virtud". Segundo, porque puede hacer pensar que la verdad es un bien jurídico penal, ello es tan cierto como decir que la justicia o la seguridad jurídica son intereses penalmente relevantes. Tercero, porque tanto en la estafa como en las falsedades no existe un "deber de veracidad" general, sino que a lo más uno sumamente acotado en virtud de exigencias legales o consideraciones teleológicas. Tratándose de las falsedades documentales, dicho deber se vincula con una prohibición bien concreta: efectuar, en dicho soporte, afirmaciones falsas que afecten las funciones de garantía, perpetuación o prueba de los documentos.

${ }^{83}$ Fundamental Carrara, F., Programa de Derecho Criminal, Parte Especial, Volumen VII, traducción de Ortega, J. y Guerrero, J., Temis, Bogotá, 1964, pp. 1 y ss. Véase también Creus, Falsificación de documentos en general, pp. 1 y ss.; Garrido Montt, Derecho Penal, Parte Especial, pp. 13 y s.

${ }^{84}$ Tal connotación causa similares dificultades que el empleo de "mentira" en lugar de "falsedad" o "engaño".

85 Para ello véase, solamente, Puppe, I., “§ 267”, en Kindhäuser, U. et al. (edit.), Nomos Kommentar, Strafgesetzbuch, Tomo III, 4a edición, Nomos, Baden-Baden, 2013, número marginal 1 con referencias ulteriores. 
la connotación religiosa del concepto de fe pública, sigue siendo tan vaga y abstracta como ella. Específicamente en las falsedades documentales tal vaguedad y abstracción ha hecho necesaria una concreción del interés que está a la base de esos delitos, interés que se identifica con las funciones que desempeñan los documentos en el tráfico jurídico ${ }^{86}$, esto es, garantía, perpetuación y prueba de determinados contenidos ${ }^{87}$.

Las funciones que cumplen los documentos en el tráfico jurídico y cuya protección se pretende con la tipificación de las falsedades documentales se encuentran presentes, de una u otra manera, en la regulación de todas las falsedades documentales del CP. Tanto la falsificación de instrumento público como la falsificación en documento privado afectan las funciones de garantía, de perpetuación o de prueba que desempeñan dichos soportes. Y tal afectación puede referirse a todas esas funciones, o bien, a alguna de ellas en particular.

La estafa, por su parte, también ha sufrido cambios a lo largo de la historia en lo que dice relación con los intereses que ella afectaría. Así, mientras que en un comienzo, cuando la estafa apenas alcanzaba autonomía respecto de otros delitos, existían autores que sostenían que mediante dicha figura se tutelaba la "verdad" o el "derecho a la verdad" 88 , con el correr del tiempo la estafa fue adquiriendo el sentido de un ataque contra el patrimonio, ya sea privado ${ }^{89}$ o público ${ }^{90}$, mediante engaño. En este cambio relativo al carácter atribuido al delito de estafa también han surgido voces que plantean, con más o menos matices, que la estafa afecta tanto intereses patrimoniales ajenos como la libertad de disposición ${ }^{91}$. Dichas voces, sin embargo, no han logrado imponerse frente a la concepción de la estafa como delito contra intereses patrimoniales ajenos.

El perjuicio en el tipo penal de estafa es, en todo caso, un perjuicio patrimonial. Los argumentos que pueden plantearse para fundamentar dicha aserción son múltiples. Por solo destacar algunos debe mencionarse la ubicación sistemática de la figura, en el Título IX del Libro II CP, dedicado a los delitos contra la propiedad. La noción de "propiedad" ha sido interpretada tradicionalmente en sentido amplio ${ }^{92}$, como un concepto

${ }^{86}$ Cfr. Rodríguez Collao, L.; Vera Vega, J., "El bien jurídico protegido en los delitos de falsedad", en Revista de Derecho de la Universidad Católica de Temuco, No 5, 2004, p. 131.

${ }^{87}$ Freund, G., Urkundenstraftaten, $2^{\text {a }}$ edición, Springer, Heidelberg, 2010, p. 12, número marginal 24; Silva Sánchez, "Las falsedades documentales”, pp. 289 y s.; Villacampa Estiarte, La Falsedad Documental, p. 93.

${ }^{88}$ Cfr., por ejemplo, Cucumus, Ueber das Verbrechen des Betrugs, p. 70; Pawlik, M., Das unerlaubte Verhalten beim Betrug, Carl Heymanns Verlag, Köln, 1999, pp. 115 y ss. con referencias ulteriores.

${ }^{89}$ Véase, solamente, Fischer, Strafgesetzbuch und Nebengesetze, § 263, número marginal 3.

${ }^{90}$ Hefendehl, "§ 263”, número marginal 7. Tal es el caso de la denominada "estafa de subvenciones". Relativo al punto véase, solamente, Cugat Mauri, M., “Art. 308”, en Córdoba Roda, J. y García Arán, M. (dirs.), Comentarios al Código Penal, Parte Especial, Tomo I, Marcial Pons, Madrid, 2004, p. 1237 y Mayer Lux, L., "Obtención fraudulenta de prestaciones estatales", en Revista de Derecho de la Pontificia Universidad Católica de Valparaíso, Volumen XXXII, Semestre I, 2009, pp. 283 y ss.

${ }^{91}$ Cfr. Jakobs, G., "Die objektiv-individuelle Schadensermittlung beim Betrug - OLG Köln, NJW 1976, 1222”, en Juristische Schulung, 1977, p. 230; Niggli, M. A., "Ultima Ratio?”, en Schweizerische Zeitschrift für Strafrecht, Tomo 111, 1993, p. 257; Pawlik, Das unerlaubte Verbalten beim Betrug, p. 105.

${ }^{2}$ Cfr., solamente, Oliver, G., Delitos contra la propiedad, Legal Publishing, Santiago, 2013, p. 35. 
equivalente al de interés patrimonial ${ }^{93}$. A partir de ello puede afirmarse que las figuras del Título IX, Libro II CP inciden -en algún sentido- en intereses patrimoniales ajenos ${ }^{94}$. En aquellos delitos que afectan tales intereses en tanto universalidad jurídica, la estafa es el "delito patrimonial por antonomasia" 95 , idea que, ciertamente, no puede plantearse respecto de la falsificación de instrumento privado.

El carácter patrimonial del perjuicio en el delito de estafa puede fundamentarse, además, en el empleo del verbo defraudar en los artículos 467 ("defraudare”), 468 ("defraudare”), 469 números 1, 2 y 5 ("cometieren defraudaciones", "defraudaren", “cometieren defraudación”), 470 número 9 ("defraudar"), 473 (“defraudare”), todos del CP. Pues bien, la voz "defraudar", en materia penal, es interpretada en el sentido de perjudicar patrimonialmente a otro (por determinados medios) ${ }^{96}$.

De acuerdo con el artículo 197 CP, la falsificación de instrumento privado debe ser cometida “con perjuicio de tercero". Como apunta Londoño, a propósito de los delitos de los artículos 197 y 198 CP, "la mera falsificación -sin más- no es delito"97. Ahora bien, el legislador no limita ese perjuicio a uno de índole patrimonial ${ }^{98}$, no obstante dicho supuesto sea de frecuente ocurrencia ${ }^{99}$. En este orden de ideas, el tipo, de acuerdo con el origen y la evolución histórica de las figuras falsarias, aparece redactado en términos bastante amplios ${ }^{100}$, utilizando simplemente la voz "perjuicio", sin restringirla a un daño o menoscabo de índole material ${ }^{101}$. A ello se agrega la ubicación de la figura, dentro del Título IV del Libro II CP -reservado a los delitos contra la fe pública, a las falsificaciones, al falso testimonio y al perjurio-, circunstancia que hace pensar que la lesión del bien jurídico no implica, necesariamente, un daño a intereses patrimoniales ajenos.

93 Gössel, K.H., Strafrecht Besonderer Teil, Tomo 2, C.F. Müller, Heidelberg, 1996, p. 308, número marginal 1; Rivacoba, M., El delito de contrato simulado, Editorial ConoSur, Santiago, 1992, pp. 17 y ss.

${ }^{94}$ A diferencia de la estafa, las figuras pluriofensivas de dicho Título, vgr. el robo, contienen referencias expresas a otros intereses diversos de los estrictamente patrimoniales.

${ }^{95}$ Gaede, K., “\$ 263”, en Leipold, K. et al. (edit.), Anwaltkommentar StGB, Deutscher Anwaltverlag, Bonn, 2011, número marginal 1.

96 Por todos Mera, Fraude civil y penal, pp. 84 y ss.

${ }^{97}$ Londoño, F., "Comentario a la STOP de Calama de 30 de septiembre de 2008 (RUC: $0410000245-$ 6)", en Doctrina y Jurisprudencia Penal, No 3, 2010, p. 67 (cursiva en el original).

98 Chauveau, A.; Helie, F., Theorie du Code Pénal, $3^{\text {a }}$ edición, Cosse, Paris, 1852, pp. 368 y ss. En contra SCA de Concepción, de 8 de enero de 2008, Rol: 2202-2005, fundamento jurídico segundo; SCA de Puerto Montt, de 2 de julio de 2008, Rol: 113-2008, fundamento jurídico cuarto; Etcheberry, Derecho Penal, Parte Especial, Tomo IV, p. 174.

${ }^{99}$ Que exista una estrecha relación entre las falsedades y los delitos contra intereses patrimoniales (cfr. Freund, Urkundenstraftaten, p. 4, número marginal 7) resulta evidente, sobre todo si se tiene en cuenta que una falsedad puede ser empleada como medio para la comisión de un delito patrimonial. Lo que aquí quiere destacarse es que también es posible la afectación de otra clase de intereses, más allá de los patrimoniales.

${ }^{100}$ Casas Barquero, El delito de falsedad, pp. 295 y ss. Véase también Labatut, Derecho Penal, p. 59.

101 Si bien la voz "perjuicio", de acuerdo con el Diccionario de la RAE, puede ser entendida como "[d] etrimento patrimonial que debe ser indemnizado por quien lo causa", o bien, como "[i] ndemnización que se ha de pagar por este detrimento" (así, la segunda y tercera acepción de "perjuicio" contenida en dicho Diccionario), "perjuicio" también puede entenderse como "[e]fecto de perjudicar" (así, la primera acepción de "perjuicio”, cfr. ibíd.), y "perjudicar” es "[o]casionar daño o menoscabo material o moral” (cfr. ibíd.). 
Sostener que la ubicación de un delito no es decisiva para la delimitación de su injusto es correcto, pero no tomarla en cuenta, en este caso, puede poner en duda la necesidad del tipo de falsificación de instrumentos privados respecto del delito de estafa y, en particular, de la denominada estafa residual del artículo 473 CP. Si ambos delitos suponen engaño y perjuicio patrimonial, y si la amplitud de las normas de la estafa no se opone a su comisión mediante documentos privados falsos ¿para qué regular una figura en otro Título del Libro II CP que, frente a la estafa, se torna del todo prescindible? ${ }^{102}$ Que en ciertos casos de falsedad la pena sea mayor que en la estafa ${ }^{103}$ no hace sino confirmar que para el legislador chileno hay en la falsificación de documentos privados algo particular, que no se agota en lo puramente patrimonial.

En el sentido que aquí se plantea son varios los autores que admiten la posibilidad de que en virtud de la falsedad en instrumentos privados se produzca un perjuicio de intereses personales de la víctima ${ }^{104}$. Así, por ejemplo, Freund plantea el caso de que el sujeto activo (por celos) falsifique una carta de A y se la envíe a la novia de A, afirmándole (falsamente) que A no quiere volver a verla y provocando, con ello, que la novia de A se aleje de él ${ }^{105}$. También puede pensarse que el agente, que odia a B, falsifica el texto del obituario que debía publicarse en un diario de circulación nacional, colocando al hijo de $\mathrm{B}$ dentro de las personas fallecidas. En fin, puede ocurrir que el sujeto activo, que envidia a $\mathrm{C}$, falsifique el diploma que reconoce a C como el mejor alumno de su promoción, introduciendo su propio nombre, o bien, el nombre de un tercero en el diploma aludido.

Consiguientemente, la falsificación de documentos privados tendría una naturaleza ambivalente, revistiendo un carácter análogo al de una defraudación ${ }^{106}$, o no, según implique o no un perjuicio patrimonial. Sea que se verifique un perjuicio patrimonial o de otra índole - perjuicio que es necesario para la imposición del castigo del artículo 197 CP-, la falsificación de instrumentos privados supondrá, en todo caso, un ataque

102 En el mismo sentido Quintero Olivares, G., "Sobre la falsedad en documento privado", en Revista Jurídica de Cataluña, $\mathrm{N}^{\circ}$ 1, 1976, p. 40: "Si no tuviese sentido propio la falsedad bastaría con los preceptos que reprimen las infracciones patrimoniales, ya consumadas, ya intentadas".

103 Londoño, "Comentario a la STOP de Calama de 30 de septiembre de 2008 (RUC: $0410000245-$ 6)”, p. 66 con nota 32.

${ }^{104}$ Cfr. Bustos Ramírez, Obras Completas, p. 625, quien admite que se verifique "cualquier perjuicio en el tráfico jurídico"; también Casas Barquero, El delito de falsedad, p. 295 en relación con p. 297, con referencia expresa a la posibilidad de que se lesione el honor.

${ }^{105}$ Cfr. Freund, Urkundenstraftaten, p. 5, número marginal 10. Véase también Quintero Olivares, "Sobre la falsedad", p. 39, aludiendo al supuesto de la falsa carta de amor que prueba un adulterio.

${ }^{106}$ Ese sería un caso en que tanto la estafa como la falsificación de instrumento privado constituirían fraudes por engaño, cuestión que difiere de afirmar que la falsificación de instrumento privado sea una estafa especial. Que la falsificación de documentos privados afecte la funcionalidad del documento provoca que, aun en un caso como el aludido, su injusto no se limite al que es propio de un fraude por engaño, extendiéndose, necesariamente, a algo que va más allá del mismo. Similar Quintero Olivares, "Sobre la falsedad", pp. 57 y s. 
al interés patrimonial o personal afectado y a las funciones de garantía, perpetuación o prueba $^{107}$ que ha de cumplir dicho soporte material en el tráfico jurídico ${ }^{108}$.

\section{Diferencias entre la falsificación de instrumentos privados y la estafa desde el punto de vista de la función del "perjuicio" exigido}

El tipo penal de estafa es un delito de resultado ${ }^{109}$ y ese resultado no es otro que el perjuicio patrimonial de un tercero ${ }^{110}$. Esto obliga a distinguir, por una parte, el comportamiento típico y, por otra, el resultado delictivo, debiendo existir entre conducta y resultado una relación de causalidad. En el caso de la estafa, el comportamiento delictivo es el engaño, este debe provocar el perjuicio patrimonial de la víctima. Si bien tradicionalmente se sostiene que el resultado típico en el delito de estafa es la lesión del (activo del) patrimonio, dicha afirmación debe ser precisada, teniendo en cuenta la pluralidad de elementos integrantes de dicha figura delictiva. Aunque la conducta típica en la estafa se agota en el engaño, el resultado típico tendrá un carácter complejo y estará integrado por el error, por la disposición patrimonial y por el perjuicio patrimonial de la víctima. De esta forma, mientras que la conducta delictiva será el engaño típico, el resultado delictivo será la disposición patrimonial perjudicial determinada por error.

En cambio, la caracterización de la falsedad de documento privado como tipo de resultado es discutida, discusión que se vincula con la función que desempeña el perjuicio en dicho delito, a saber, si acaso cumple el rol de resultado del tipo ${ }^{111}$, como en la estafa, o si, en cambio, juega el papel de condición objetiva de punibilidad ${ }^{112}$. Desde el punto de vista del castigo de ambos delitos, ninguna de dichas opciones resulta satisfactoria.

${ }^{107}$ Fundamental Villacampa Estiarte, La Falsedad Documental, pp. 84 y ss., p. 94 . Véase también Quintero Olivares, "Sobre la falsedad", pp. 37 y ss., centrándose en la función de prueba del documento privado.

${ }^{108}$ Esta concepción del bien jurídico pretende superar los inconvenientes -básicamente formales- de la tesis que identifica el interés tutelado con la fe privada (cfr. Rivacoba, M., "Cheque y estafa", en Gaceta Jurídica, $\mathrm{N}^{\circ} 112,1989$, p. 11), denominación opuesta a la de fe pública, tradicionalmente considerada el objeto jurídico de la falsificación de instrumentos públicos (por todos Etcheberry, Derecho Penal, Parte Especial, Tomo IV, p. 136). Por su parte, advierten una afectación del patrimonio y de la fe pública SCA de Temuco, de 25 de noviembre de 2005, Rol: 929-2005, fundamento jurídico cuarto; SCA de Valparaíso, de 31 de mayo de 2012, Rol: 519-2012, fundamento jurídico quinto; Garrido Montt, Derecho Penal, Parte Especial, p. 87.

${ }^{109}$ Hefendehl, “\$ 263”, número marginal 8; Pérez Manzano, M., “Acerca de la imputación objetiva de la estafa", en Hacia un derecho penal económico europeo, Jornadas en honor del profesor Klaus Tiedemann, BOE, 1995 , p. 285, pp. 290 y s.; Rebollo, R., "Propuestas para la controversia en la delimitación típica del delito de estafa: la distinción con el fraude civil y la reinterpretación del engaño”, en Revista de Derecho y Proceso Penal, No 19, 2008, p. 114.

${ }^{110}$ Por todos Tiedemann, "§ 263”, número marginal 3.

${ }^{111}$ A favor de que la falsificación de instrumento privado sea un delito de resultado Etcheberry, Derecho Penal, Parte Especial, Tomo IV, pp. 174 y ss.; Garrido Montt, Derecho Penal, Parte Especial, p. 87.

${ }^{112}$ Así Ortiz Muñoz, P., "La falsificación de instrumento privado (Ensayo de Construcción Jurídica del Delito en Chile)", en Revista de Ciencias Penales, Tomo VII, 1944, pp. 212 y s. Respecto de la discusión véase Londoño, "Comentario a la STOP de Calama de 30 de septiembre de 2008 (RUC: 0410000245-6)", p. 57, p. 64; Vargas, "Comentario a la SCA de Antofagasta de 27 de junio de 2008 (ROL: 117-2008)", pp. 86 y s. 
La falsificación de instrumento privado contempla, tanto en lo relativo a la conminación abstracta como a la aplicación concreta de la pena, una sanción que, en términos generales, es superior a la del tipo penal de estafa. De un lado, la falsificación de documentos privados prevé una pena de simple delito fija y que no depende de la cuantía del perjuicio de tercero ${ }^{113}$ (artículo 197 CP). En cambio, en la estafa, la cuantía de lo defraudado determina si estamos ante un simple delito o ante una falta, así como qué pena de simple delito será la aplicable (artículo 467 en relación con artículo 494 número 19 CP). De otro lado, tratándose de la falsificación de instrumentos privados, el juez solo puede prescindir de aplicar la pena de multa ("según las circunstancias"), pero está obligado, en todo caso, a imponer la pena privativa de la libertad de presidio menor en cualquiera de sus grados. En la estafa, por su parte, el juez debe aplicar una pena pecuniaria, salvo que el monto de lo defraudado exceda de una unidad tributaria mensual.

Pues bien, si se estima que la pena de la falsificación de instrumentos privados es, comparativamente, mayor que la de la estafa, podría pensarse que el perjuicio en el primero de tales delitos es, efectivamente, un resultado del tipo. La mayor gravedad de la figura tendría que conllevar una tipificación que, además de la tentativa, admita la frustración. De ser así, la falsificación de documentos privados sería un delito de resultado, al igual que la estafa. Tal razonamiento abre varias interrogantes vinculadas tanto con la sanción de formas imperfectas de ejecución del delito como con el carácter del perjuicio exigido. Por ejemplo, si ese "resultado" fuera un perjuicio patrimonial, ¿por qué falsificar un documento privado justificaría un tratamiento penal más severo (con castigo de etapas imperfectas de ejecución y pena más alta) que el de la estafa cometida por medio de un engaño que no esté plasmado en dicho soporte? De otro lado, si el "resultado" fuera un perjuicio no patrimonial, vgr. relativo al honor, ¿por qué falsificar un documento privado que afecta el honor fundamentaría un tratamiento penal más severo (con castigo de etapas imperfectas de ejecución y pena más alta) que una afectación del honor llevada a cabo por escrito? ${ }^{114}$

La mayor pena de la falsificación de instrumentos privados en relación con el tipo de estafa también podría hablar en favor de atribuirle al perjuicio de tercero del artículo 197 CP el carácter de condición objetiva de punibilidad. En efecto, para muchos

113 Cfr. Ortiz Muñoz, "La falsificación de instrumento privado", p. 211. Dicha cuantía, a lo sumo, puede servir para imponer únicamente la pena privativa de la libertad y no la pecuniaria, así como una sanción ubicada dentro de las menores que el tipo permite, si el perjuicio es bajo; o, por el contrario, imponer tanto la pena privativa de la libertad y la pecuniaria, así como una sanción ubicada dentro de las mayores que el tipo permite, si el perjuicio es alto.

${ }^{114}$ Afectaciones al honor que, dicho sea de paso, se encuentran tipificadas como figuras de mera actividad (artículos 412 y ss. CP). En relación con el honor, puede agregarse ¿por qué falsificar un documento privado que implica una afectación del honor justificaría idéntico tratamiento penal que la falsificación de instrumentos privados con perjuicio patrimonial de tercero? ¿Acaso no se encuentra ya suficientemente tutelado el honor con las normas contenidas en el Título VIII del Libro II CP, relativas a los delitos de injurias y calumnia? ¿Por qué en este caso la acción penal podría ser pública, mientras que en los delitos de injurias y calumnia -aun cuando se cometan por escrito- son de acción penal privada? En el mismo sentido Casas Barquero, El delito de falsedad, p. 297 y Quintano Ripollés, La falsedad documental, p. 240. 
autores, la consagración a nivel típico de condiciones objetivas de punibilidad solo se justifica si el injusto del comportamiento típico, que debe ser abarcado por el dolo, es suficientemente grave ${ }^{115}$. Aunque las condiciones objetivas de punibilidad no tienen que estar cubiertas por el dolo del agente -cuestión que puede resultar criticable en consideración al principio de culpabilidad-, de lo que se trata es de estar en presencia de un comportamiento cuyo merecimiento de pena no dependa de un elemento externo -en este caso, el perjuicio de tercero- que, además, no tiene que haber sido conocido ni querido por el sujeto activo ${ }^{116}$.

Con todo, la consagración de condiciones objetivas de punibilidad admite, asimismo, otra interpretación. Los tipos penales que las exigen se caracterizan por una suerte de "todo o nada", es decir, si se comete el comportamiento típico y se da la condición, hay castigo; si aquella no se da, la conducta, aunque se encuentre consumada, quedará impune. Para que ello resulte razonable esa conducta, que queda impune, debería tener escasa gravedad, pues si la tuviera, más acertado sería dar cabida al castigo de formas imperfectas de ejecución del delito. Si pensamos en algunos de los delitos de la Parte Especial del CP que, según parte importante de la doctrina, contemplan condiciones objetivas de punibilidad, constataremos que se trata, en general, de comportamientos de escaso desvalor jurídico penal. En ese orden de ideas, si se estima que en el hurto de posesión ${ }^{117}$ o en la apropiación indebida ${ }^{118}$ el perjuicio constituye una condición objetiva de punibilidad, se estaría consagrando dicho instituto respecto de dos delitos, cuya necesidad de pena, más allá de su reprochabilidad en el ámbito del Derecho privado, no es del todo evidente. Algo parecido puede decirse del giro fraudulento de cheques, en que el protesto y la notificación del mismo también tendrían el carácter de condiciones objetivas de punibilidad $^{119}$. La muerte del suicida, cuyo carácter de condición objetiva de punibilidad algunos vinculan con consideraciones de política criminal ${ }^{120}$, también puede interpretarse en el sentido de que, prestar auxilio a la realización de una conducta que no es delictiva, constituye un comportamiento de escasa gravedad jurídico-penal.

Ahora bien, el legislador chileno no parece atribuir a la falsificación de instrumentos privados una gravedad escasa, al menos no, si comparamos su pena con la de la estafa. Ello hace dudar del hecho que el perjuicio exigido en el artículo $197 \mathrm{CP}$ sea, efectivamente, una condición objetiva de punibilidad. Si ese fuera el caso, su falta de concurrencia provocaría una exclusión del castigo de formas imperfectas de ejecución del delito, a diferencia de lo que acontece respecto del tipo penal de estafa, que admite tanto tentativa como frustración.

115 Cfr., por ejemplo, Kindhäuser, U., Strafrecht Allgemeiner Teil, $5^{\text {a }}$ edición, Nomos, Baden-Baden, 2011, p. 58. Véase también Soto Piñeiro, M., "Sobre los límites entre el ilícito civil y el penal. El caso de la apropiación indebida”, en Revista de Derecho y Jurisprudencia, Tomo XC, No 1, 1993, p. 22.

116 Kindhäuser, Strafrecht Allgemeiner Teil, p. 58.

117 Así, por ejemplo, Oliver, Delitos contra la propiedad, p. 189.

118 Cfr. Politoff., S., El delito de apropiación indebida, Editorial ConoSur, Santiago, 1992, p. 262.

119 Rivacoba, "Cheque y estafa”, pp. 4 y ss.

${ }^{120}$ Véase Politoff; Matus; Ramírez, Lecciones, p. 158 con referencias ulteriores. 
En realidad, todo parece indicar que el perjuicio en la falsificación de instrumentos privados no es ni un resultado del tipo ni una condición objetiva de punibilidad, sino que tiene un carácter sui generis y opera como un requisito de antijuridicidad material. La concurrencia de dicho requisito permite legitimar el castigo penal de la falsificación de instrumentos privados, agregando, a su naturaleza supraindividual, ligada con las funciones del documento en el tráfico jurídico, un componente individual, vinculado con el perjuicio para un tercero.

En la falsificación de documentos privados la imposición del castigo punitivo quedará, de esta forma, supeditada a la afectación de un bien jurídico "peculiar de la misma falsedad" 121 , así como a la verificación de un daño para terceros. Solo así podrá justificarse materialmente la incriminación de un comportamiento que, en principio, debería interesar exclusivamente al Derecho privado y acarrear únicamente consecuencias civiles $^{122}$.

Por otra parte, como se ha planteado respecto de los delitos contra la función pública, los intereses supraindividuales no deben tutelarse en cuanto tales, sino que solo en la medida en que su afectación incida en personas de carne y hueso ${ }^{123}$. Lo mismo ha de regir para la falsificación de instrumentos privados, en la que no se protegen las funciones de garantía, de perpetuación o de prueba de ese instrumento en cuanto tales, sino que solo en la medida en que su afectación implique perjuicio para un tercero.

\section{BIBLIOGRAFÍA}

Aguilar Aranela, C., Delitos Patrimoniales, Editorial Metropolitana, Santiago, 2008.

AlCÁcer Guirao, R., "Cómo cometer delitos con el silencio. Notas para un análisis del lenguaje de la responsabilidad", en de Toledo y Ubieto, E.O. et al. (coord.), Estudios penales en recuerdo del profesor Ruiz Antón, Tirant lo Blanch, Valencia, 2004, pp. 21-54.

Alejandre, J.A., "Estudio histórico del delito de falsedad documental", en Anuario de Historia del Derecho Español, Tomo XLII, 1972, pp. 117-187.

Antón Oneca, J., "Estafas”, en Mascareñas, C.E. (dir.), Nueva Enciclopedia Jurídica, Tomo IX, Editorial Francisco Seix, Barcelona, 1958, pp. 56-90.

Austin, J.L., How to do things with words, $2^{a}$ edición, Harvard University Press, Cambridge, 1975. Balmaceda, G., "El delito de estafa en la jurisprudencia chilena", en Revista de Derecho de la Universidad Austral de Chile, Volumen XXIV, julio 2011, pp. 59-85.

Bullemore, V.R.; Mackinnon, J.R., Curso de Derecho Penal, Parte Especial, Tomo III, LexisNexis, Santiago, 2005.

121 Soto Nieto, F., "Las falsedades en documento privado. El uso del documento falso como medio para cometer una estafa", en Las falsedades documentales, Libro homenaje a Enrique Ruiz Vadillo, Comares, Granada, 1994, p. 170.

122 Con referencia a la legislación española, exige únicamente un perjuicio para terceros, a fin de fundamentar el castigo penal de la conducta Quintano Ripollés, La falsedad documental, p. 235.

${ }^{123}$ Rodríguez Collao; Ossandón Widow, Delitos contra la función pública, p. 99. 
Bustos Ramírez, J., Obras Completas, Derecho Penal, Parte Especial, Tomo III, $2^{\text {a }}$ edición, Ediciones Jurídicas de Santiago, Santiago, 2009.

Calle Rodríguez, M. V., Falsedades documentales no punibles, Editoriales de Derecho Reunidas, Madrid, 1998.

Carrara, F., Programa de Derecho Criminal, Parte Especial, Volumen IV, traducción de Ortega, J. y Guerrero, J., Temis, Bogotá, 1959.

Carrara, F., Programa de Derecho Criminal, Parte Especial, Volumen VII, traducción de Ortega, J. y Guerrero, J., Temis, Bogotá, 1964.

Casas Barquero, E., El delito de falsedad en documento privado, Bosch, Barcelona, 1984.

Chauveau, A.; Helie, F., Theorie du Code Pénal, $3^{a}$ edición, Cosse, Paris, 1852.

Cousiño, L., "La falsificación de instrumento privado (1) (Ensayo de Construcción Jurídica del Delito en Chile)", en Revista de Ciencias Penales, Tomo VII, 1944, pp. 5-23.

Creus, C., Falsificación de documentos en general, $3^{a}$ edición, Astrea, Buenos Aires, 1999.

Cucumus, C., Ueber das Verbrechen des Betrugs, als Beytrag für Criminalgesetzgebung. Ein Programm, Nitribitt, Würzburg, 1820.

Cugat Mauri, M., “Art. 308”, en Córdoba Roda, J. y García Arán, M. (dirs.), Comentarios al Código Penal, Parte Especial, Tomo I, Marcial Pons, Madrid, 2004, pp. 1232-1245.

Donna, E.A., Derecho Penal, Parte Especial, Tomo II-B, Rubinzal-Culzoni, Buenos Aires, 2001. DonNA, E.A., "El bien jurídico en los delitos contra la fe pública", en Urquizo Olaechea, J. (dir.), Modernas tendencias de dogmática penal y política criminal, Libro homenaje al Dr. Juan Bustos Ramírez, Idemsa, Lima, 2007, pp. 267-277.

D'ors, A., "Contribuciones a la historia del 'crimen falsi", en Studi in onore di Edoardo Volterra, Tomo II, Giuffrè, Milán, 1969, pp. 527-558.

Etcheberry, A., Derecho Penal, Parte Especial, Tomos III y IV, reimpresión de la $3^{\text {a }}$ edición, Editorial Jurídica de Chile, Santiago, 2010.

Ferruccio, G., Diritto Penale Romano, Volumen II, R. Zannoni, Padova, 1932.

Fischer, T., Strafgesetzbuch und Nebengesetze, 58 edición, Beck, München, 2011.

Fontán Balestra, C., Derecho Penal, Parte Especial, 16ª edición actualizada por G. Ledesma, Abeledo-Perrot, Buenos Aires, 2002.

Freund, G., Urkundenstraftaten, $2^{\mathrm{a}}$ edición, Springer, Heidelberg, 2010.

Frisch, W., "Funktion und Inhalt des 'Irrtums' im Betrugstatbestand”, en Kaufmann, A. et al. (edit.), Festschrift für Paul Bockelmann zum 70. Geburtstag, Beck, München, 1979, pp. 647-667.

GAEDE, K., “\$ 263”, en Leipold, K. et al. (edit.), Anwaltkommentar StGB, Deutscher Anwaltverlag, Bonn, 2011.

García Cantizano, M., Falsedades documentales (En el Código Penal de 1995), Tirant lo Blanch, Valencia, 1997.

García Cavero, P., Nuevas formas de aparición de la criminalidad patrimonial, Jurista Editores, Lima, 2010.

Garrido Montt, M., Derecho Penal, Parte Especial, Tomo IV, $4^{a}$ edición, Editorial Jurídica de Chile, Santiago, 2008.

GiUfFrè, V., La repressione criminale nell'esperienza romana, 5ª edición, Jovene, Nápoles, 1998.

GonZÁlez Rus, J.J., "Delitos contra el patrimonio y contra el orden socioeconómico (V). Las defraudaciones. La estafa", en Morillas Cueva, L. (coord.), Sistema de Derecho Penal Español, Parte Especial, Dykinson, Madrid, 2011, pp. 481-511.

Gössel, K.H., Strafrecht Besonderer Teil, Tomo 2, C. F. Müller, Heidelberg, 1996.

Guzmán Brito, A., Derecho Privado Romano, Tomo II, Editorial Jurídica de Chile, Santiago, 1997.

GuZMán Dalbora, J.L., El delito de amenazas, Legal Publishing, Santiago, 1999. 
Habermas, J., Theorie des kommunikativen Handelns, Tomo 1, Suhrkamp, Frankfurt am Main, 1995. Habermas, J., Wahrheit und Rechtfertigung, Suhrkamp, Frankfurt am Main, 2004.

Hefendehl, R., "§ 263”, en Joecks, W. y Miebach, K. (edits.), Münchener Kommentar, Strafgesetzbuch, Tomo 4, Beck, München, 2006.

Hernández, H., "Aproximación a la problemática de la estafa”, en Cury, E. et al., Problemas Actuales de Derecho Penal, Universidad Católica de Temuco, Temuco, 2003, pp. 147-190.

Jakовs, G., "Die objektiv-individuelle Schadensermittlung beim Betrug - OLG Köln, NJW 1976, 1222”, en Juristische Schulung, 1977, pp. 228-231.

Jakoвs, G., Falsedad documental, Revisión de un delito de engaño, traducción de López Barja de Quiroga, J.; Rey Sanfiz, L.C., Marcial Pons, Madrid, 2011.

Jiménez de Asúa, L., Crónica del Crimen, $7^{\text {a }}$ edición, LexisNexis, Buenos Aires, 2005.

Kindhäuser, U., "§ 263”, en Kindhäuser, U. et al. (edit.), Nomos Kommentar, Strafgesetzbuch, Tomo III, $4^{a}$ edición, Nomos, Baden-Baden, 2013.

Kindhäuser, U., Strafrecht Allgemeiner Teil, $5^{\text {a }}$ edición, Nomos, Baden-Baden, 2011.

Labatut, G., Derecho Penal, Tomo II, reimpresión de la $7^{\mathrm{a}}$ edición actualizada por el profesor J. Zenteno, Editorial Jurídica de Chile, Santiago, 2012.

LaCKNer, K., "§ 263”, en Jescheck, H. et al. (edit.), Leipziger Kommentar, Strafgesetzbuch, Großkommentar, Tomo 6, $10^{a}$ edición, Walter de Gruyter, Berlin, 1988.

LONDOÑo, F. "Comentario a la STOP de Calama de 30 de septiembre de 2008 (RUC: 0410000245 6)", en Doctrina y Jurisprudencia Penal, No 3, 2010, pp. 55-67.

Magaldi Paternostro, M.J., “Arts. 248 a 254”, en Córdoba Roda, J. y García Arán, M. (dirs.), Comentarios al Código Penal, Parte Especial, Tomo I, Marcial Pons, Madrid, 2004, pp. 739-860.

MAÑALICH, J.P., “¿La comisión de delitos mediante la imputación de delitos? Los delitos contra el honor bajo la teoría de los actos de habla”, en Revista Peruana de Doctrina y Jurisprudencia Penales, $\mathrm{N}^{\circ}$ 6, 2005, pp. 193-242.

MAYER Lux, L., Die konkludente Täuschung beim Betrug, V\&Ruprecht unipress - Bonn University Press, Göttingen, 2013.

Mayer Lux, L., "Obtención fraudulenta de prestaciones estatales”, en Revista de Derecho de la Pontificia Universidad Católica de Valparaíso, Volumen XXXII, Semestre I, 2009, pp. 283-325.

Mera, J., Fraude civil y penal. El delito de entrega fraudulenta, reimpresión de la $3^{a}$ edición, Legal Publishing, Santiago, 2005.

Merkel, A., "Die Lehre vom strafbaren Betruge", en El mismo, Kriminalistische Abhandlungen, Tomo II, reimpresión de la edición de Leipzig de 1867, Detlev Auverman, Glashütten im Taunus, 1971.

Mitsch, W., Strafrecht Besonderer Teil 2, Vermögensdelikte (Kernbereich), Parte 1, 2a edición, Springer, Berlin, 2003.

Mommsen, T., El Derecho Penal Romano, Tomo 2, traducción de Dorado, P., La España Moderna, Madrid, 1898.

Niggli, M.A., "Ultima Ratio?”, en Schweizerische Zeitschrift für Strafrecht, Tomo 111, 1993 , pp. 236-263.

Oliver, G., Delitos contra la propiedad, Legal Publishing, Santiago, 2013.

Ortiz Muñoz, P., "La falsificación de instrumento privado (Ensayo de Construcción Jurídica del Delito en Chile)", en Revista de Ciencias Penales, Tomo VII, 1944, pp. 207-214.

Pawlik, M., Das unerlaubte Verhalten beim Betrug, Carl Heymanns Verlag, Köln, 1999.

Pérez Manzano, M., "Acerca de la imputación objetiva de la estafa", en Hacia un derecho penal económico europeo, Jornadas en honor del profesor Klaus Tiedemann, BOE, Madrid, 1995, pp. 285-309. 
PIÑA, J.I., "Comentario a la SCA de Copiapó de 5 de octubre de 2000 sobre la imposibilidad de consumar la estafa con la disposición patrimonial de quien no ha sufrido el engaño (ROL 75087-2000)", en Doctrina y Jurisprudencia Penal, No 2, 2010, pp. 97-102.

PIÑA, J.I., Fraude de Seguros, $2^{a}$ edición, Editorial Jurídica de Chile, Santiago, 2006.

Polaino Navarrete, M.; Polaino-Orts, M., Cometer delitos con palabras, Teoría de los actos de habla y funcionalismo jurídico-penal, Dykinson, Madrid, 2004.

Politoff., S., El delito de apropiación indebida, Editorial ConoSur, Santiago, 1992.

Politoff, S.; Matus, J.P.; Ramírez, M.C., Lecciones de Derecho Penal chileno, Parte Especial, $2^{a}$ edición, Editorial Jurídica de Chile, Santiago, 2005.

Puppe, I., “\$ 267”, en Kindhäuser, U. et al. (edit.), Nomos Kommentar, Strafgesetzbuch, Tomo III, $4^{a}$ edición, Nomos, Baden-Baden, 2013.

Puppe, I., Die Fälschung technischer Aufzeichnungen, Duncker \& Humblot, Berlin, 1972.

Quintero Olivares, G., "Sobre la falsedad en documento privado", en Revista Jurídica de Cataluña, $N^{\circ} 1,1976$, pp. 31-62.

Quintano Ripollés, A., La falsedad documental, Instituto Editorial Reus, Madrid, 1952.

Rebollo, R., "Propuestas para la controversia en la delimitación típica del delito de estafa: la distinción con el fraude civil y la reinterpretación del engaño", en Revista de Derecho y Proceso Penal, No 19, 2008, pp. 93-118.

Rivacoba, M., "Cheque y estafa”, en Gaceta Jurídica, No 112, 1989, pp. 3-12.

Rivacoba, M., El delito de contrato simulado, Editorial ConoSur, Santiago, 1992.

Rodríguez Collao, L.; Ossandón Widow, M.M., Delitos contra la función pública, $2^{a}$ edición, Editorial Jurídica de Chile, Santiago, 2008.

Rodríguez Collao, L.; Vera Vega, J., "El bien jurídico protegido en los delitos de falsedad", en Revista de Derecho de la Universidad Católica de Temuco, N 5, 2004, pp. 109-137.

Rojas, L.E., "Historia dogmática de la falsedad documental", en Revista de Derecho de la Pontificia Universidad Católica de Valparaíso, Volumen XXXIX, Semestre II, 2012, pp. 545-583.

Romero, G., Delito de estafa, 2 2a edición, Hammurabi, Buenos Aires, 1998.

Ruiz Antón, L.F., "La acción como elemento del delito y la teoría de los actos de habla: cometer delitos con palabras", en ADPCP, Tomo LI, 1998, pp. 5-34.

Schaffstein, F., "Das Delikt des Stellionatus in der gemeinrechtlichen Strafrechtsdoktrin. Eine Studie zur Entstehungsgeschichte des Betrugstatbestandes", en Behrends, O. et al. (edit.), Festschrift für Franz Wieacker zum 70. Geburtstag, Vandenhoeck \& Ruprecht, Göttingen, 1978, pp. 281-295.

Schilling, G., Der strafrechtliche Schutz des Augenscheinsbeweises. Ein Beitrag zur Lehre von der Beweismittelfälschung, Ludwig Röhrscheid, Bonn, 1965.

Schmidhäuser, E., Strafrecht Besonderer Teil, $2^{a}$ edición, Mohr, Tübingen, 1983.

Silva Sánchez, J.M., "Las falsedades documentales", en él mismo (dir.), Lecciones de Derecho Penal, Parte Especial, Atelier, Barcelona, 2006, pp. 287-301.

Soler, S., Derecho Penal Argentino, Tomo IV, $3^{a}$ reimpresión total, Tipográfica Editora Argentina, Buenos Aires, 1956.

Soto Nieto, F., "Las falsedades en documento privado. El uso del documento falso como medio para cometer una estafa", en Las falsedades documentales, Libro homenaje a Enrique Ruiz Vadillo, Comares, Granada, 1994, pp. 161-196.

Soto Piñeiro, M., "Sobre los límites entre el ilícito civil y el penal. El caso de la apropiación indebida", en Revista de Derecho y Jurisprudencia, Tomo XC, No 1, 1993, pp. 7-27.

Tiedemann, K., "Vor $§ 263$ ” “ “\$ 263”, en Laufhütte, H.W. et al. (edit.), Leipziger Kommentar, Strafgesetzbuch, Großkommentar, Tomo 9, Parte 1, $12^{\text {a }}$ edición, Walter de Gruyter, Berlin, 2012. 
VArgas, T., "Comentario a la SCA de Antofagasta de 27 de junio de 2008 (ROL: 117-2008)", en Doctrina y Jurisprudencia Penal, $N^{\circ} 3$, 2010, pp. 83-88.

VARgas, T., “'Daño del engaño' en documentos privados. Aproximación al perjuicio en la falsificación de instrumentos privados", en Revista de Derecho de la Universidad Austral de Chile, Volumen XXIV, diciembre 2011, pp. 179-204.

VARGas, T., “'Engaño patrimonial' y perjuicio. Análisis desde la práctica nacional”, en Doctrina y Jurisprudencia Penal, No 2, 2010, pp. 51-60.

Villacampa Estiarte, C., La Falsedad Documental: análisis jurídico-penal, Cedecs, Barcelona, 1999.

Wittgenstein, L., "Philosophische Untersuchungen", en Werkausgabe Band 1, Suhrkamp, Frankfurt am Main, 2006, pp. 224-580.

Yubero, J., El engaño en el delito de estafa, 2a edición, Editorial Cruz del Sur, Santiago, 2010. 
